\title{
Analysis of Online Learning Implementation and Learning Independence Based on Learning Management System in Electrical Engineering Education Students of Nusa Cendana University
}

\author{
Yetursance Y. Manafe; Louis F. Beosday; Maria M. E. Bere \\ Nusa Cendana University, East Nusa Tenggara, Indonesia \\ http://dx.doi.org/10.18415/ijmmu.v8i12.3305
}

\begin{abstract}
The dynamics of the application of learning from time to time always changes according to the times and also certain situations. In early 2019, offline learning must adapt to online learning conditions due to the covid-19 pandemic that has hit the whole world. Online learning is carried out using various platforms, one of which is the Learning Management System (LMS). The aim of this study are: to analyze the implementation of online learning and LMS-based independent learning in Electrical Engineering Education students at Nusa Cendana University. The method used is descriptive qualitative using data collected on google form as many as 24 questions. The research subjects were 267 students in the Electrical Engineering Education Study Program. The results obtained by the lecturers are the key in fostering independence and learning success using LMS based on 6 indicators that provide the largest contribution, namely: (1). High authority, discipline, responsibility and commitment by $77.90 \%$, (2). Good communication is $77.53 \%$, (3) Supporting the Graduate Profile and CPL (Graduate Learning Outcomes) of Study Program is 76.03\%. (4) Availability of RPS (Semester Learning Plan) of 75.66\% (5) The suitability of RPS with study program curriculum is 74.53 (6). The learning method that encourages students to learn actively (independently) is $71.91 \%$. The conclusion of this study, the role of lecturers is the key in growing independence and learning success using LMS.
\end{abstract}

Keywords: Independent Learning; LMS; Online Learning; Electrical Engineering Education

\section{Introduction}

The dynamics of the application of learning from time to time always experience many changes according to the times and certain situations. At the beginning of 2019, learning that had been carried out in conventional forms in this case face-to-face learning gradually had to adapt to new conditions or the new normal related to the covid pandemic experienced throughout the world. Learning in the new normal is currently changing the order in the implementation of learning. The application of learning that has been carried out face-to-face has shifted and is dominated by learning using various online/network facilities. In this study, the learning facilities that will be investigated use the Learning Management System (LMS) at the University of Nusa Cendana with the web address www.elearning.undana.ac.id. The use of LMS is in line with the learning approach which has also undergone many changes in the learning structure, usually adjusted to a certain time and place, currently learning anytime and anywhere, and 
flexibly giving students the freedom to learn. Research by Bersin et al (2009) shows that more than 70 percent of large companies have an LMS already and almost a third of these companies are considering replacing or upgrading this system with an integrated talent management system. The advantage of LMS is that this software can make it easier for humans to process administrative and learning data using the internet. LMS allows a student or students to register from a remote place that has internet access. They can also learn without having to meet face to face in class. Around 34,628 schools and universities in Indonesia already have internet access, it's just a matter of whether they want to implement it or not. The drawback is that LMS is difficult to implement in areas without internet access, such as remote areas. This can lead to disparities between one region and another. In the end there will be marginalized groups, namely people who are far from technology. Therefore, there needs to be an effort from internet service providers and the government as policy makers to expand the coverage area of the internet.

\section{Literature Review}

Even though the way and approach to learning has undergone adjustments, several things that become a benchmark for someone to learn still apply, one of which is learning through asking. The Greek philosophers Socrates, Plato and Aristotle also applied learning by educating their students by asking questions and tracing answers through questions again until they found the detailed point of the answerer's answer. This is the most basic learning pattern and one of the basic teaching skills is the questioning skill. Independent Learning is a learning approach that asks students to ask themselves who, what, where, and how questions when they learn something. This refers more to meaningful learning which refers to the theory of humanism and is also related to one's self-motivation as expressed by Kolb about reflective active learning. Referring to research that has been done by learning experts who say that one way to create active learning conditions is to stimulate students to investigate or study the subject matter themselves, this simple strategy stimulates asking questions, which is the key to learning or in other words learning starts from questions (Siberman, 2014). Trianto (2007) in his book writes that a person's knowledge always starts with asking questions. Almost all learning activities can apply questioning, including questions between students and students. Furthermore, according to Trianto (2007) the activity of asking questions is also found when students discuss, work in groups, when they encounter difficulties, and when observing. Through reciprocal peer questioning learning strategies lead to engagement with others and can create opportunities for students to evaluate and improve their mastery (Gauvain, 2001). Research conducted which also refers to asking questions is Independent Learning where students are directed to be able to explore the material they are studying by asking themselves questions regarding what, where, how the material they are studying, the purpose of submitting this personal question. will help students to reflect on what they have learned.

Learning development by asking self questions will help students to develop their analytical skills as well as retention rate. The selection of Independent Learning in its application can be adapted to learning conditions using LMS facilities because students will get a lot of time and can flexibly build basic questions or development questions that need solutions as part of reflecting on the learning they are currently following and at the same time by building questions. Self-questioning trains students to develop their metacognitive abilities so that the achievement of retention and meaning in a material can be achieved. The application of Independent Learning cannot be separated from the courses that are applied to the LMS platform, while the subjects studied are students of the Electrical Engineering Education Study Program. In this study, the platform used in the delivery of learning as well as the application of Independent Learning is the Learning Management System (LMS). The use of this LMS is based on the main consideration, namely as a learning medium developed by the University of Nusa Cendana. In this LMS the features provided are also complete, including being able to do virtual face-toface. However, the most important thing is that the uploaded material can be studied by students and then they are asked to develop the ability to ask themselves or Independent Learning, and in developing

Analysis of Online Learning Implementation and Learning Independence Based on Learning Management System in Electrical Engineering Education Students of Nusa Cendana University 
questions to themselves can be done flexibly after the material is uploaded and given directions by the lecturer. With flexible time, it can provide sufficient space for students to be able to reflect on the subject matter they are studying. Based on some of the existing descriptions and explanations, it is deemed necessary to conduct a study of the self-assessment strategy or Independent Learning in Electrical Engineering Education Study Program students using the Learning Management System (LMS) media.

\section{Research Methods}

\section{Research Design}

This research is a non-experimental research, which is classified as a qualitative descriptive research. The instrument used in this research is a questionnaire which will be filled out by the research subjects using a google form. The questionnaire/questionnaire contains 24 written questions that are used to obtain information from research subjects related to students' reflection and metacognition abilities. The questionnaire/questionnaire instrument was not tested but only validated by linguists to avoid ambiguity or double meaning of the questions in it.

In terms of how to answer it, the questionnaire/questionnaire used is included in a closed questionnaire, because the research subject has provided the answer. Judging from the answers, the questionnaire used in this study is a direct questionnaire because the research subject directly answers about himself.

\section{Research Subject}

This research was carried out at the Electrical Engineering Education Study Program, amounting to 267 students.

\section{Research Procedure}

The technique/method used in collecting data in this research is a questionnaire/questionnaire technique:

1) Questionnaire data obtained from each respondent will be recapitulated based on the questions given through the help of a google form consisting of 24 questions

2) From each question, the next assessment grid is made based on the existing grid, an assessment score is taken according to the results of the checks given by the students

3) Furthermore, the scores obtained are added up so that in each group the questions of independence and learning motivation will produce a certain value.

4) Drawing conclusions from the scores from the questionnaire on the google form by looking at the results of the acquisition scores that provide categories

5) After that, a recapitulation will be made in the form of:

a. The percentage of motivational tendencies of the students of the Electrical Engineering study program;

b. The percentage of independence tendencies of Electrical Engineering Education students

\section{Results and Discussion}

\section{Research Data Result}

This research was conducted at the Electrical Engineering Education Study Program, FKIP Nusa Cendana University. To obtain data, the google form is used as a means to obtain research data. Research data according to existing research indicators are shown in table 1 to table 6. 
Table 1. General Perception

\begin{tabular}{|c|c|c|c|}
\hline Very good \& Good & 47.94 & 39.70 & 61.80 \\
\hline Enough & 34.19 & 39.55 & 28.43 \\
\hline Not good & 20.97 & 24.34 & 12.36 \\
\hline Number of item & 1 & 2 & 3 \\
\hline
\end{tabular}

Table 2. Substance of Online Learning

\begin{tabular}{|c|c|c|c|c|c|}
\hline Very good \& Good & 53.18 & 64.04 & 76.03 & 75.66 & 67.04 \\
\hline Enough & 36.25 & 29.25 & 18.95 & 19.78 & 24.31 \\
\hline Not good & 13.86 & 9.36 & 6.74 & 6.37 & 10.86 \\
\hline Number of item & 4 & 5 & 6 & 7 & 8 \\
\hline
\end{tabular}

Table 3. Preparation for Online Learning

\begin{tabular}{|c|c|c|c|}
\hline Very good \& Good & 59,18 & 74,53 & 64,42 \\
\hline Enough & 21,84 & 23,90 & 22,25 \\
\hline Not good & 20,97 & 3,75 & 15,36 \\
\hline Number of item & 9 & 10 & 11 \\
\hline
\end{tabular}

Table 4. Online Learning Process

\begin{tabular}{|c|c|c|c|}
\hline Very good \& Good & 60,30 & 59,93 & 59,93 \\
\hline Enough & 30,49 & 33,37 & 30,49 \\
\hline Not good & 11,99 & 9,74 & 12,36 \\
\hline Number of item & 12 & 13 & 14 \\
\hline
\end{tabular}

Table 5. Suporting Environment

\begin{tabular}{|c|c|c|c|c|c|c|}
\hline $\begin{array}{c}\text { Very good \& } \\
\text { Good }\end{array}$ & 62,55 & 68,54 & 66,29 & 64,42 & 65,54 & 49,06 \\
\hline Enough & 26,37 & 25,13 & 26,37 & 28,84 & 29,66 & 31,31 \\
\hline Not good & 13,48 & 8,61 & 9,74 & 9,36 & 7,49 & 22,47 \\
\hline Number of item & 15 & 16 & 17 & 18 & 19 & 20 \\
\hline
\end{tabular}


Table 6. Lecturer Profesionalism

\begin{tabular}{|c|c|c|c|c|}
\hline Very good \& Good & 61,80 & 71,91 & 77,53 & 77,90 \\
\hline Enough & 30,90 & 22,25 & 19,36 & 16,48 \\
\hline Not good & 10,11 & 7,87 & 4,87 & 7,12 \\
\hline No Butir Soal & 21 & 22 & 23 & 24 \\
\hline
\end{tabular}

\section{Discussion}

Based on the questions on the google form, the indicators that describe each question item are as follows:

Table 7. Indicator of Statement Items and Percentage of Answers

\begin{tabular}{|c|c|c|}
\hline $\begin{array}{l}\text { Number } \\
\text { of Item }\end{array}$ & Indicators & Answers (\%) \\
\hline & A. General Perception & \\
\hline 1 & Love online learning & 47.94 \\
\hline 2 & Understanding the material through online learning & 39.37 \\
\hline \multirow[t]{2}{*}{3} & Access online learning & 61.80 \\
\hline & B. Substance of online learning & \\
\hline 4 & Nature of Learning materials & 53.18 \\
\hline 5 & Up-to-date materials and references & 64.04 \\
\hline 6 & $\begin{array}{l}\text { Supports Graduate Profile and CPL (Graduate Learning Outcomes) of } \\
\text { Study Program. }\end{array}$ & 76.03 \\
\hline 7 & Availability of RPS (Semester Learning Plan) & 75.66 \\
\hline \multirow[t]{2}{*}{8} & Explanation of RPS at the beginning of learning & 67.04 \\
\hline & C. Preparation for online learning & \\
\hline 9 & Planned form of learning & 59.18 \\
\hline 10 & The compatibility of the RPS with the study program curriculum & 74.53 \\
\hline \multirow[t]{2}{*}{11} & The online learning platform used & 64.92 \\
\hline & D. Online Learning Process & \\
\hline 12 & The attractiveness of presenting material & 60.30 \\
\hline 13 & Variety of learning activities & 59.93 \\
\hline \multirow[t]{2}{*}{14} & Material presentation structure & 59.93 \\
\hline & E. Suporting Environment & \\
\hline 15 & Accessibility to online learning websites & 62.55 \\
\hline 16 & Availability of learning materials in online learning LMS & 68.54 \\
\hline 17 & Discussion opportunities in online learning LMS & 66.29 \\
\hline 18 & Assessment Objectivity & 64.42 \\
\hline 19 & result feedback & 65.54 \\
\hline \multirow[t]{2}{*}{20} & Remedial and enrichment measures & 49.08 \\
\hline & F. Lecturer Profesionalism & \\
\hline 21 & Mastering the material being taught & 61.80 \\
\hline 22 & $\begin{array}{l}\text { Using learning methods that encourage students to learn actively } \\
\text { (independently). }\end{array}$ & 71.91 \\
\hline 23 & Communicate and treat students well. & 77.53 \\
\hline 24 & Demonstrate authority, discipline, responsibility, and high commitment. & 77.90 \\
\hline
\end{tabular}


Based on the research data adjusted to the question items and also the presentation of the answers for each question item, it can be displayed on the graph shown in Figure 1.

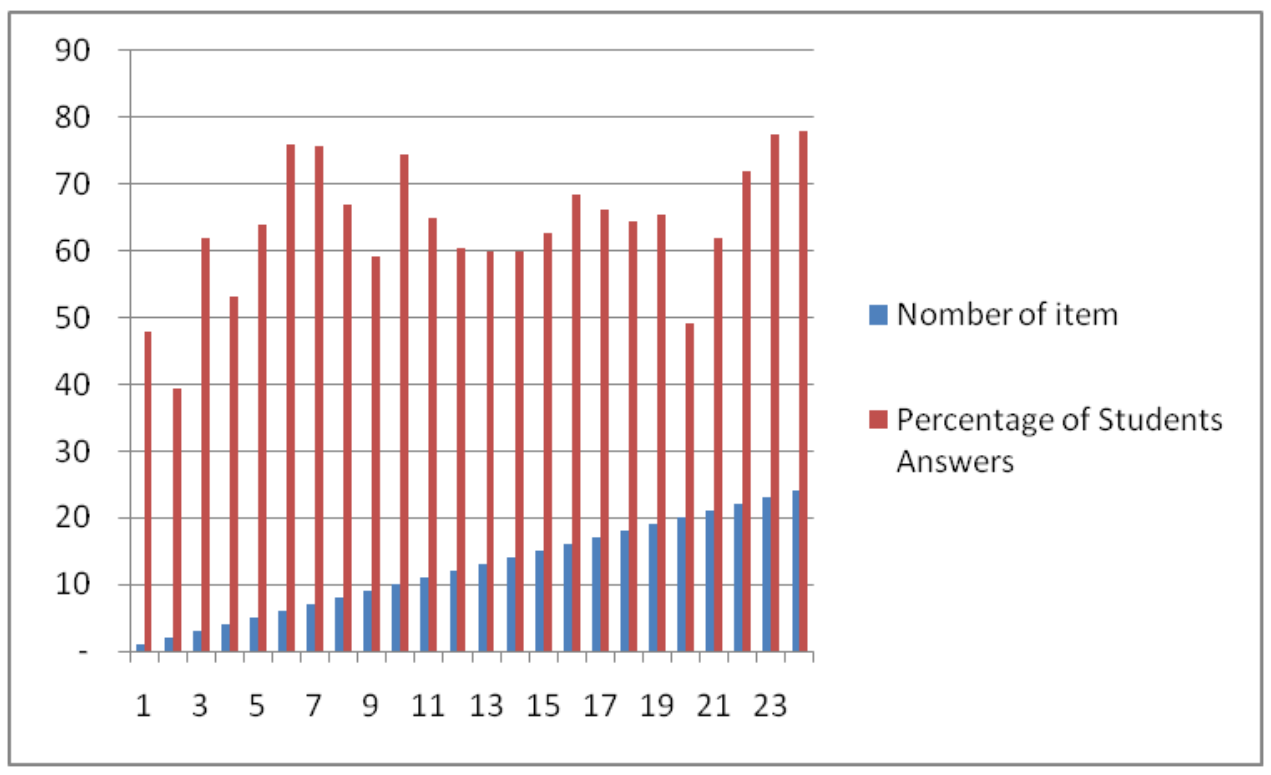

Figure 1. Percentage of student answers

Based on the research data shown in table 1 and also figure 1, it shows that the indicator of lecturer professionalism is an important indicator to support students to achieve independence in doing LMS-based learning. Lecturers who have high authority, discipline, responsibility and commitment have a positive influence on students to achieve their independence. This is in accordance with the opinion of expert Abdul Majid (2013) who stated that the basic concept of an independent learning system is the arrangement of learning programs that are organized in such a way, so that each student can choose or determine their own learning materials and progress. Lecturers who have discipline and responsibility will help organize learning programs, including using the LMS platform.

Rusman (2014) states that students who are very independent in learning have the following characteristics. 1) Knowing with certainty what is to be achieved in their learning activities, therefore students want to participate in determining the learning objectives. 2) Can choose their own learning resources and know how they can find the learning materials they want and learn not to depend on others. 3) Have not been able to assess their own abilities, because they prefer learning programs that already have criteria clear success. To achieve this characteristic of independence, the role of the lecturer is needed to facilitate students to learn actively and independently through the selection of the right method in the LMS. Based on the results of the study, it shows that lecturers are the key in growing independence and learning success using LMS.

Based on 6 indicators that provide the largest contribution, namely: (1). High authority, discipline, responsibility and commitment by $77.90 \%$, (2). Good communication is $77.53 \%$, (3) Supporting the Graduate Profile and CPL (Graduate Learning Outcomes) of Study Program is 76.03\%. (4) Availability of RPS (Semester Learning Plan) of $75.66 \%$ (5) The suitability of RPS with study program curriculum is 74.53 (6). The learning method that encourages students to learn actively (independently) is $71.91 \%$. The conclusion of this study, the role of lecturers is the key in growing independence and learning success using LMS. 


\section{Conclusion}

Based on the results obtained from the questionnaire on google form, it can be concluded that the role of lecturers is the key in growing independence and learning success using LMS based on 6 indicators that provide the largest contribution, namely: (1). High authority, discipline, responsibility and commitment by $77.90 \%$, (2). Good communication is $77.53 \%$, (3) Supporting the Graduate Profile and CPL (Graduate Learning Outcomes) of Study Program is $76.03 \%$. (4) Availability of RPS (Semester Learning Plan) of $75.66 \%$ (5) The suitability of RPS with study program curriculum is 74.53 (6). The learning method that encourages students to learn actively (independently) is $71.91 \%$. The conclusion of this study, the role of lecturers is the key in growing independence and learning success using LMS. Other supporting factors that must be owned by lecturers are accessibility to online learning websites, mastering the material being taught, online learning platforms used, accessing online learning, the nature of learning materials, variety of learning activities, structure of material presentation, attractiveness of material presentation, planned learning forms, likes online learning, understands material through online learning.

\section{References}

Asmani, Jamal Ma'mur. 2011. Buku Panduan Internalisasi Pendidikan Karakter di Sekolah. Jogjakarta: DIVA Press.

Bersin, Josh; Howard, Chris; O'Leonard, Karen; Mallon, David (2009), Learning Management Systems 2009, Bersin \& Associates.

Gauvain, M. 2001. The Social Context of Cognitive Development. New York: Guilford.

Majid, Abdul. 2013. Strategi Pembelajaran. Bandung: PT Remaja Rosdakarya.

Rusman. 2014. Model-Model Pembelajaran. Jakarta: PT Raja Grafindo Persada.

Siberman, M., L. 2014. Active Learning: 101 Cara Belajat Siswa Aktif. Edisi Revisi-cetakan X. Bandung: Nuansa Cendekia.

Trianto. 2007. Interaksi dan Motivasi Dalam Belajar. Jakarta: Raja Grafindo Persada.

\section{Copyrights}

Copyright for this article is retained by the author(s), with first publication rights granted to the journal.

This is an open-access article distributed under the terms and conditions of the Creative Commons Attribution license (http://creativecommons.org/licenses/by/4.0/). 